\title{
Do conspecific populations exhibit divergent phenological patterns? A study case of widespread savanna species
}

\author{
Dinnie Michelle Assunção Lacerda ${ }^{\mathrm{a}, *}$, Judá Ben-Hur de Araújo Barros ${ }^{\mathrm{b}}$, \\ Eduardo Bezerra de Almeida Jr. $^{c}$, Davi Rodrigo Rossatto ${ }^{d}$ \\ ${ }^{a}$ Universidade Federal do Maranhão, Programa de Pós Graduação em Biodiversidade e Biotecnologia - Rede Bionorte, Campos Universitário do Bacanga, 1966, 65080- \\ 805, São Luís, Maranhão, Brazil \\ b Instituto Federal de Educação, Ciência e Tecnologia do Maranhão, Campus Barreirinhas, 65590-000, Barreirinhas, Maranhão, Brazil \\ c Universidade Federal do Maranhão, Departamento de Biologia, Laboratório de Estudos Botânicos - LEB, Campos Universitário do Bacanga, 1966, 65080-805, São Luís, \\ Maranhão, Brazil \\ d Faculdade de Cências Agrárias e Veterinárias, Univ. Estadual Paulista (UNESP), Campus de Jaboticabal, 14884-900, Jaboticabal, SP, Brazil
}

\section{A R T I C L E I N F O}

\section{Edited by Fei-Hai Yu}

Keywords:

Cerrado

Day length

Phenology

Seasonality

Temperature

\begin{abstract}
A B S T R A C T
Widespread savanna tree species can grow and survive at sites that diverge in water availability and seasonality, thus these species may be able to adjust their phenology in response to site variations. Here we evaluated vegetative and reproductive phenology in five woody species whose populations grow at two savannas sites under divergent climatic regimes, inserted in a large transitional zone between the Amazon forest and the semiarid region. Patterns of leaf fall, leaf flush and flowering were recorded monthly for five woody species growing under longer (LDS) and shorter (SDS) dry seasons. We evaluated the seasonality, the start and peak dates for phenological events and the associations between phenophases and climatic data. We found a close relationship between phenological events and site temperatures, with phenological peaks in the LDS occurring, in general, about one to three months later than at the SDS site. Leaf fall coincides with warmer and drier periods when the day length is shorter. Leaf production and flowering were associated with increased day length in some populations. Our results support the hypothesis that the conspecific populations have a high degree of association with climatic variables, especially temperature and day length, showing distinct phenological responses associated to the local climatic differences.
\end{abstract}

\section{Introduction}

Phenological events are associated with a wide variety of ecological processes (Forrest and Miller-Rushing, 2010), and are therefore important to our understanding of species-level relationships (Goulart et al., 2005; Zalamea et al., 2011; Dalmolin et al., 2015) and adaptive mechanisms (Grogan and Schulze, 2012; Worbes et al., 2013; Guan et al., 2014). Phenology can also explain the temporal organization of plant communities (Stevenson et al., 2008; Kushwaha et al., 2011; Diez et al., 2012; Hawes and Peres, 2016; Ryan et al., 2017), because phenological events are linked to climatic and biotic factors (Pau et al., 2011; Tang et al., 2016), affecting the capacity of plants to acquire resources for growth and reproduction (Nord and Lynch, 2009; Nord et al., 2011).

Phenological responses of plant communities may diverge between sites, even if those sites are similar in species composition (Forrest et al., 2010). This suggests that climatic parameters are a stronger influence than species identity in determining phenological behavior (Pau et al., 2011). This may be especially evident for plant communities of the Brazilian savanna (Cerrado), where it is possible to find a great variety of phenological patterns following climatic variations along an extensive latitudinal and altitudinal gradient (Bulhão and Figueiredo, 2002; Batalha and Martins, 2004; Pirani et al., 2009; Silva et al., 2011; Rossatto 2013). The wide climatic variations in the Cerrado are due to its occurrence in disjunctive areas in the Amazon; in a continuous strip that runs from Brazil's Northeast to Center-South regions; and in the Southeast region of the country (Bridgewater et al., 2004). This continental occurrence subjects Cerrado plant communities to distinct regimes of dry season duration and annual rainfall amount (Alvares et al., 2013).

In tropical and sub-tropical regions, the amplitude in phenological events is often correlated with different climatic variables, including water availability (Dalmolin et al., 2015), photoperiod and light intensity (Yeang, 2007; Zimmerman et al., 2007) and temperature

\footnotetext{
* Corresponding author.

E-mail address: michellelacerda@yahoo.com.br (D.M.A. Lacerda).
} 
variations (Pau et al., 2013). For savannas in particular, water availability - especially its decrease during the end of the wet season - is cited as one of the main factors driving leaf fall patterns (Bulhão and Figueiredo, 2002; Lenza and Klink, 2006; Rossatto et al., 2009; Guan et al., 2014). Flowering and leaf renewal are concentrated during the dry period; but especially during the transition from the late dry to the rainy season, a time of the year when day length and temperatures increase and first rains begin to fall (Figueiredo, 2008; Lenza and Klink, 2006; Pirani et al., 2009; Borges and Prado, 2014; Dalmolin et al., 2015; Ryan et al., 2017). The production of leaves and flowers during this transitional period has some advantages for savanna plants: the canopy reaches full development and is ready for maximal carbon gain just as the first rains start (Franco et al., 2005); an early flowering allows sufficient time for the complete fruit production and seed dispersal, which increases the success of seed germination and establishment (Batalha and Martins 2004). However, if the rainy period was delayed, and plants were not plastic enough to adapt their strategies, they would suffer from prolonged drought.

Although a typical regime of alternation between dry and rainy periods prevails in the savannas, the duration of the dry season, distribution of precipitation, average air temperatures and day length duration are highly variable (Rivera et al., 2002; Silva et al., 2008; Alvares et al., 2013). Temperature and day length are considered important drivers for phenological events in savanna species (Rivera et al., 2002), especially for vegetative growth. Ascertaining how species respond to such differences enables the predictions of changes in phenological events and of population dynamics, and contributes importantly to the assessment of how climate change affects natural populations (Franco et al., 2014). The use of conspecific populations (represented by individuals of the same species, but growing at different sites) is an interesting approach to comprehend local adaptations to climatic aspects (Panchen and Gorelick, 2016).
In the present study, we evaluated vegetative and reproductive phenology in five species whose populations grow at two savannas sites (Cerrado), under distinct climatic regimes, in a large transitional zone between the Amazon forest and the semi-arid region. These sites exhibit differences in the duration of the dry season: one of them shows higher total rainfall, but a longer dry season, while the other have lower rainfall, but a shorter dry season. Additionally, short dry season site shows the highest temperature and longest day length variations earlier than the long dry season site. This study aimed to answer whether: 1) differences in the seasonal climatic patterns of these sites influence the period, start and peaks, of the phenological events, 2) phenological events are associated with temperature and day length independently of the dry season duration. We hypothesize that if phenological phenomena are intrinsically linked to climatic variables at these sites, the shorter dry season will promote phenological events to occur earlier in comparison to the longer dry season. These responses will occur because leaf events and flower production are supposedly related to temperature and day length, which increase from mid to late dry season on each site and are indicative of the following rainy period.

\section{Material and methods}

\subsection{Study sites and climate}

We conducted our study at two savanna sites (regionally known as Cerrado sensu stricto) in the northeastern region of Brazil: the first site is located at Barreirinhas municipality $\left(03^{\circ} 01^{\prime} 17^{\prime \prime} \mathrm{S}, 43^{\circ} 06^{\prime} 28^{\prime \prime} \mathrm{W}\right)$ and the second at the Mirador State Park $\left(06^{\circ} 37^{\prime} 55^{\prime \prime}\right.$ S, $\left.45^{\circ} 52^{\prime} 38^{\prime \prime} \mathrm{W}\right)$, both in Maranhão State, Brazil (Fig. 1). The climate is As in Barreirinhas, and Aw in Mirador State Park (Alvares et al., 2013), both of which are classified as tropical with two distinct seasons - dry and rainy - but differing in terms of total rainfall and in the dry season length, as

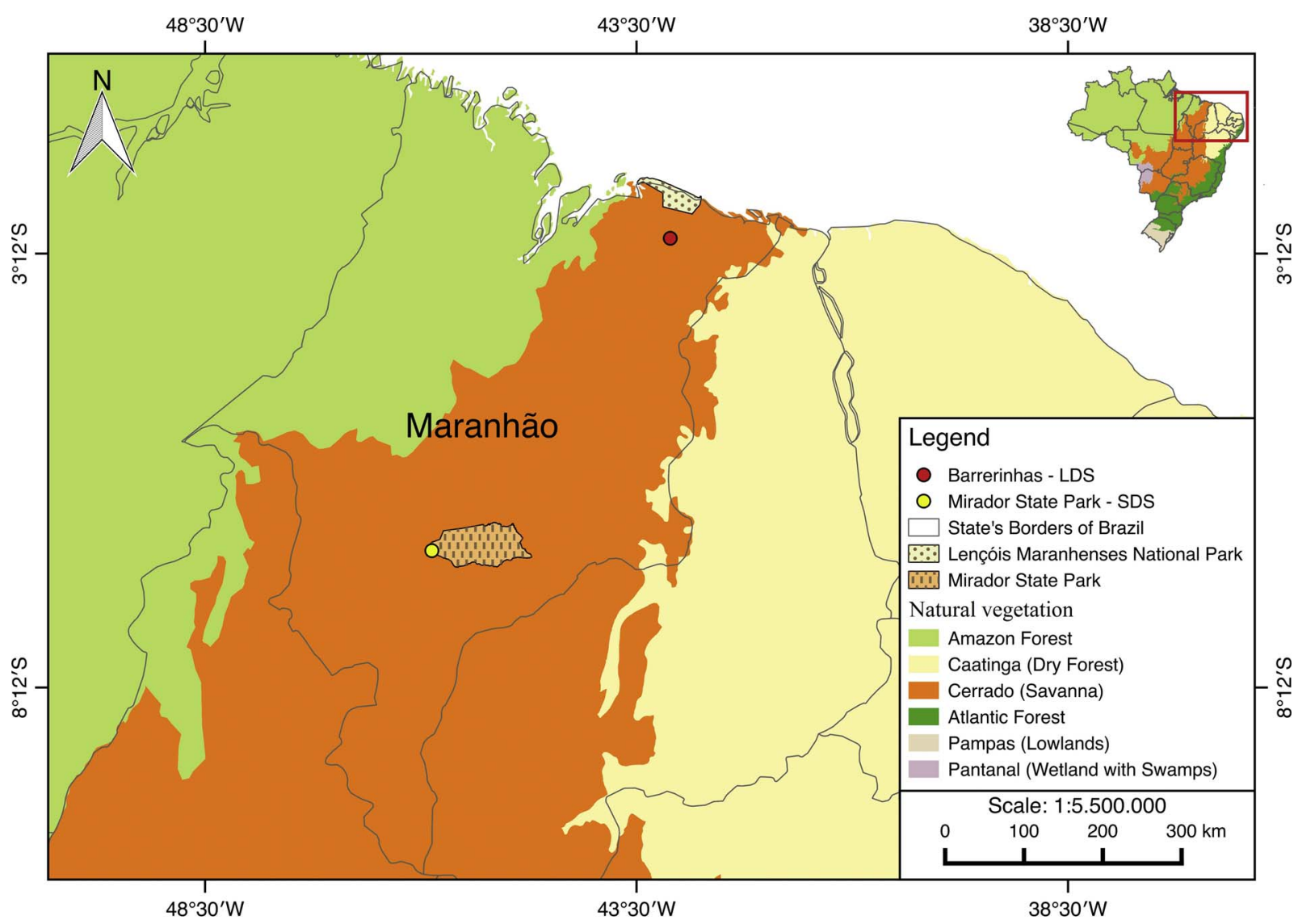

Fig. 1. Sites selected for phenological observations: Barreirinhas (longer dry season - LDS) and Mirador State Park (shorter dry season - SDS), Maranhão State, Brazil. 

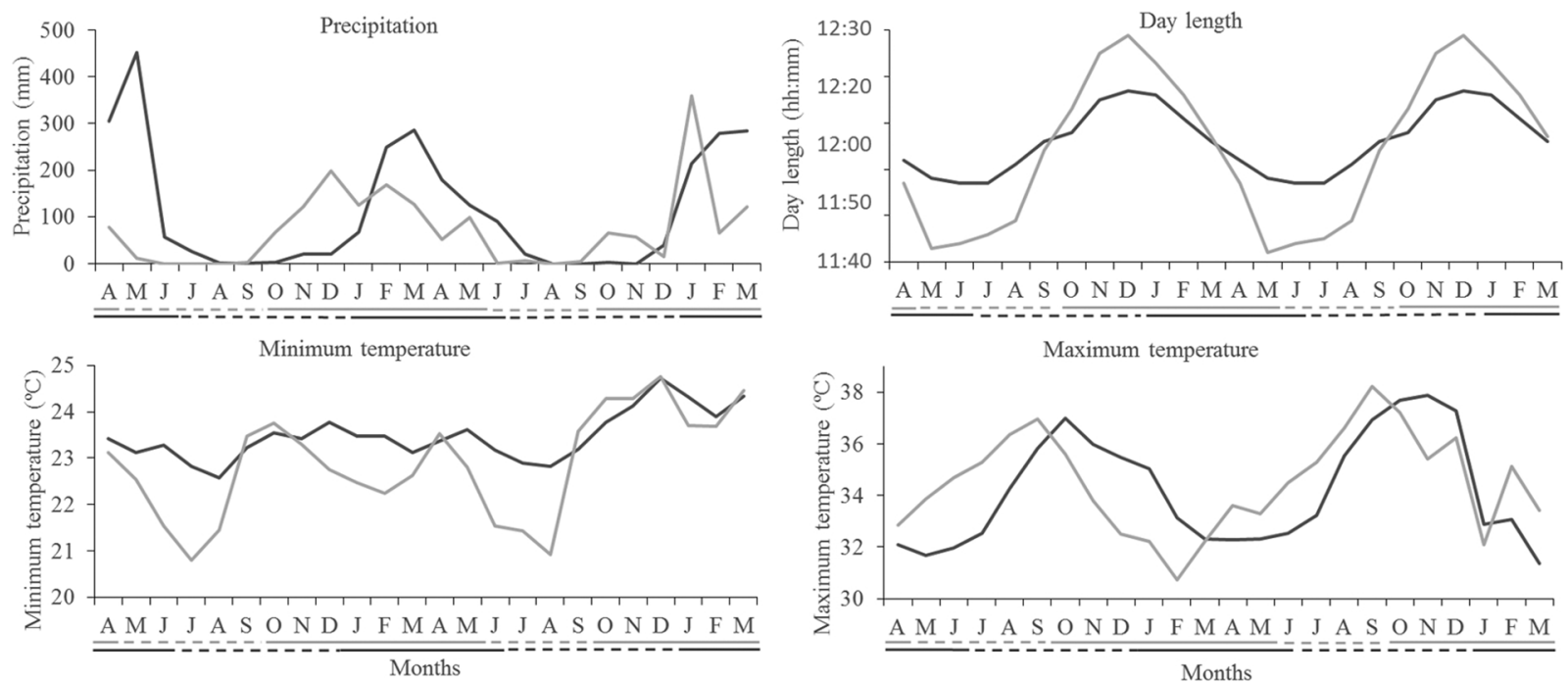

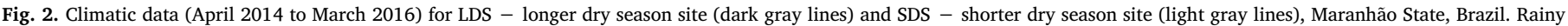
season indicated by continuous lines below the $\mathrm{x}$ axis; dry season indicated by dashed lines below the $\mathrm{x}$ axis.

observed during the study period (Fig. 2). For the sake of simplification and to clearly associate each study site with its respective climate, the Barreirinhas region will be referred to as the longer dry season (LDS) region, and Mirador State Park, as shorter dry season (SDS) region (Fig. 2).

The annual historical rainfall average for a 30 -year period in LDS (from 1986 to 2016) was $1,700 \mathrm{~mm}$; average monthly air temperature is around $27^{\circ} \mathrm{C}$, with a mean maximum of $34^{\circ} \mathrm{C}$, mean monthly minimum of $23{ }^{\circ} \mathrm{C}$, and a dry period between July and late December, when the first rains begin to fall. The thermal amplitude, considering mean monthly data, varies from 8 to $14{ }^{\circ} \mathrm{C}$ (INMET-Instituto Nacional de Meteorologia/Chapadinha Station ( $\mathrm{n}^{\circ}$ 82.382), 2017). The day length varies from $11 \mathrm{~h}$ and $57 \mathrm{~min}$ in June to $12 \mathrm{~h}$ and $18 \mathrm{~min}$ in December (Source: http://www.sci.fi/ benefon/sol.html). Altitudes around $90 \mathrm{~m}$ are predominant and the soils are sandy yellow latosols, with a high content of coarse sand and clay, being generally poorer than SDS soil (Appendix A, Supplementary material).

In SDS, the annual historical average rainfall was $1,200 \mathrm{~mm}$; the monthly mean air temperature of $27^{\circ} \mathrm{C}$, monthly mean maximum of $33^{\circ} \mathrm{C}$ and monthly mean minimum of $22{ }^{\circ} \mathrm{C}$. Although SDS and LDS sites show similar ranges of mean temperature variation, mean monthly data show that the SDS region has a greater thermal amplitude - from 7 to $16{ }^{\circ} \mathrm{C}$ (INMET, Balsas Station ( ${ }^{\circ} 82.768$ ), 2017) - , and a dry period extending from May to September. Despite little variation, the day length also has greater amplitude earlier in SDS area, going from $11 \mathrm{~h}$ and $44 \mathrm{~min}$ in June, to $12 \mathrm{~h}$ and $31 \mathrm{~min}$, in December (Source: http://www.sci.fi/ benefon/Sol.html). The altitude ranges from 300 to $600 \mathrm{~m}$, and the predominant soils in the region are litholic and yellow latosols, of the sandy loam type, with a high content of fine sand, and about $10 \%$ clay (Appendix A, Supplementary material). The monthly climatic data of total precipitation, mean maximum and mean minimum air temperatures (Source: http://www.inmet.gov.br/portal/) and day length (Source: http://www.sci.fi/ benefon/sol.html), for the period from April 2014 to March 2016, were obtained for association with the phenological data.

\subsection{Phenological study}

The vegetative (leaf fall and flush) and reproductive (flowering) phenology were recorded monthly in populations of five woody species that are common to the study sites and widely distributed in typical savanna areas of the Brazilian territory: Byrsonima crassifolia (L.) Rich. (Malpighiaceae), Caryocar coriaceum Wittm. (Caryocaraceae), Hirtela ciliata Mart. \& Zucc. (Chrysobalanaceae), Qualea grandiflora Mart. (Vochysiaceae) and Plathymenia reticulata Benth. (Fabaceae). We marked and monitored all individuals of these species in 20 plots $(20 \times 20 \mathrm{~m})$, covering $1.6 \mathrm{ha}$ at each site. We sampled individuals with a minimum of $10 \mathrm{~cm}$ of trunk circumference at the ground level. Conspecific populations presented different densities in each area, implying a different number of individuals sampled per species. The number of individuals in LDS and SDS were, respectively: 69 and 11 for B. crassifolia; 13 and 26 for $C$. coriaceum; 19 and 27 for $H$. ciliata; 28 and 48 for Q. grandiflora and 140 and 11 for $P$. reticulata. Vouchers for these species are deposited in the Universidade Federal do Maranhão herbarium (Herbarium MAR).

Over a period of two years (between April 2014 and March 2016), we made monthly visual estimates of the percentage of crown area in each individual that presented the following signs: losing brown leaves (for leaf fall); flushing new leaves (for leaf flush); flower buds and/or open flowers (for flowering). Estimates for leaf fall, leaf flush and flowering were made using a scale of five categories: $0,1,2,3$ and 4 , at intervals of $25 \%(0: 0 \% ; 1: 1-25 \% ; 2: 26-50 \% ; 3: 51-75 \%$ and 4 : 76-100\%), following the methodology described by Fournier (1974). We calculated monthly averages of the percentage for each studied population, using the sum of the intensity values obtained for all individuals and dividing by the maximum possible value (number of individuals multiplied by four). This value was converted into a percentage.

\subsection{Statistical analysis}

We applied circular statistics to detect seasonal trends at the start (the mean date in which each population manifested the phenophase for the first time) and peak dates (the mean date in which each population showed the highest value for intensity) for a given phenological event. We also compared phenological patterns between the conspecific populations at both sites. For this, the months were converted to angles at $30^{\circ}$ intervals. The circular parameters were estimated for each conspecific population (mean start and peak dates and length of mean vector ( $\mathrm{r}$ )). To test the occurrence of seasonality, the Rayleigh $\mathrm{Z}$ test was applied. If the probability value is significant, the concentration intensity around the mean angle, represented by the vector $r$, is considered as a measure of the degree of seasonality, ranging from zero to one. It was not possible to determine the mean date of leaf fall start, since the activity in this phenophase was continuous in all individuals of the evaluated species, though it differed in intensity of occurrence. 
B. crassifolia

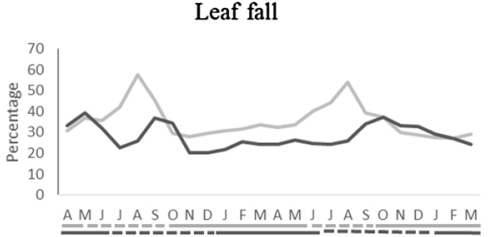

C. coriaceum

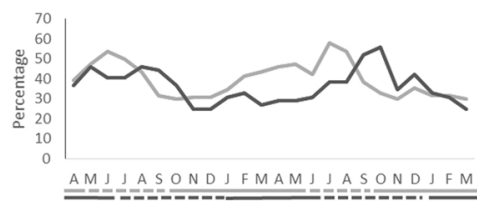

H. ciliata

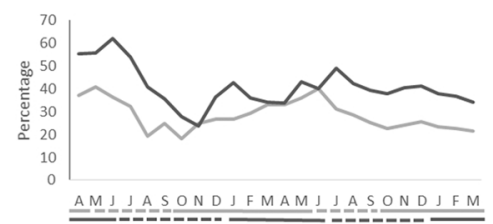

Q. grandiflora
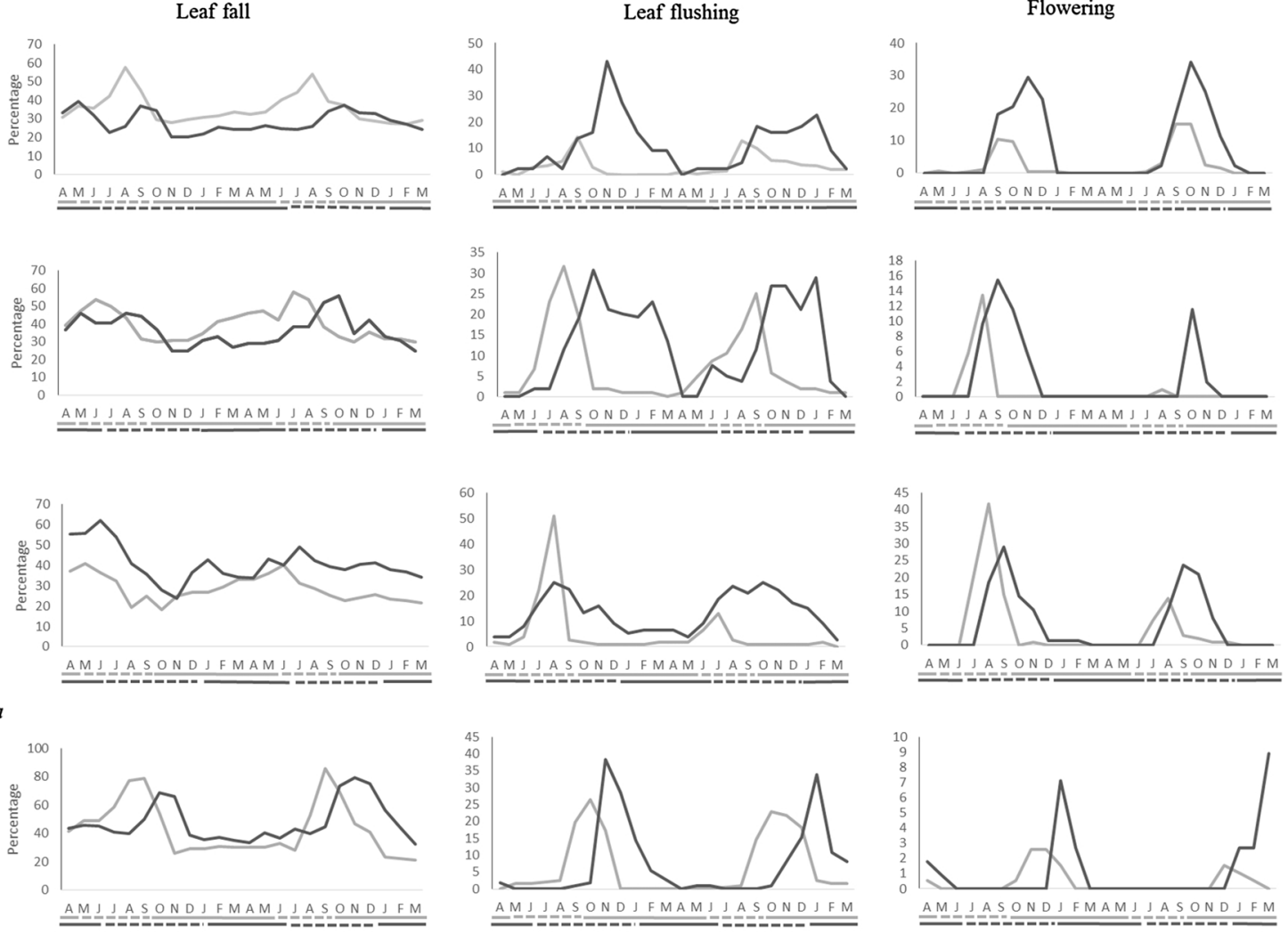

P. reticulata
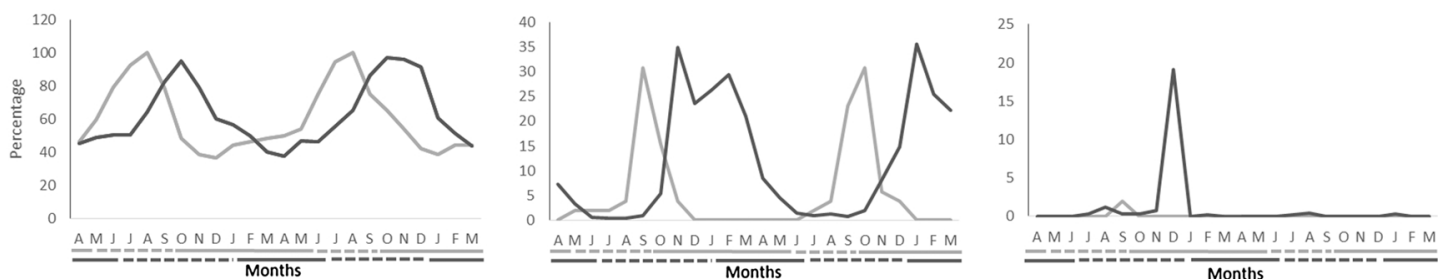

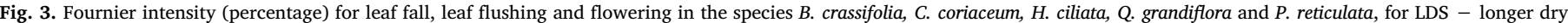

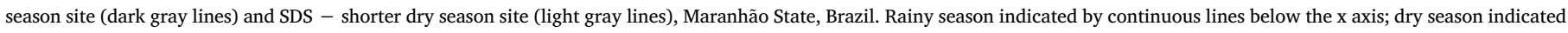
by dotted lines below the $\mathrm{x}$ axis.

We performed the Watson-Williams two-sample (F) test when the mean angle was significant, to determine whether conspecific populations exhibit a similar seasonal pattern across areas (Zar, 2010). The analyses related to circular statistics were performed in the software ORIANA 4.0 (Kovach, 2011). The species $P$. reticulata had only one flowering record in SDS and was therefore excluded from the statistical evaluations of this phenophase. In addition, we used multiple regression analysis to evaluate the association between phenological events (dependent variables) and monthly climatic variables, such as total precipitation, mean maximum and minimum air temperatures, and day length (independent variables). For these analyses, we showed only the significant relationships and the respective beta values (the effect of the independent variable on the dependent variable) (Zar, 2010).

\section{Results}

All species exhibited seasonal behavior on their peak dates of leaf fall as well on the start and peak dates of leaf flushing and flowering (Fig. 3 Table 1). In LDS, these phenomena were concentrated between July and December, whereas in SDS, they occurred from August to October, predominantly in the driest months. Independently of the species, the phenological phenomena tended to occur about one to three months earlier in SDS than in LDS (Fig. 3 Table 1).

For $B$. crassifolia, the mean start and peak dates occurred from
October to December at LDS, and from August to October in SDS. The events showed significantly different start and peak dates (Table 2), with a delay of few days to two months at LDS (Table 1). The intensity of events exhibited the same trend, with uneven distribution between sites and higher proportions occurring earlier in SDS than in LDS. The duration of leaf flushing and flowering was longer in LDS than in SDS (Fig. 3).

For C. coriaceum, the mean dates of phenophases occurred from September to November in LDS, and from August to September in SDS (Table 1), with all phenophases showing significant differences between sites (Table 2). In LDS, start and peak events for this species occurred about one to two months later than in SDS (Table 1), and the duration of leaf flushing and flowering was longer. In SDS, higher intensity percentages of all phenophases occurred earlier than in LDS (Fig. 3).

For $H$. ciliata, the mean dates occurred from July to October in LDS, and from June to August in SDS. The events followed a pattern similar to those reported for the previous species, with a delay of one to two months in LDS (Table 1), except to leaf flushing start. As for the distribution of the phenophases percentages, leaf fall had the most irregular pattern throughout the year. The highest proportions of leaf flushing and flowering intensities in SDS preceded those in LDS, where their duration was prolonged (Fig. 3).

Between Q. grandiflora populations, the mean dates of phenophases 
Table 1

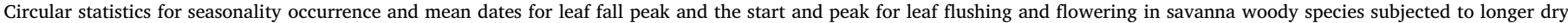

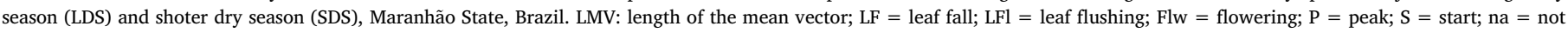
available. Significance levels: * $\mathrm{P}<0.001$.

\begin{tabular}{|c|c|c|c|c|c|c|c|c|c|c|c|}
\hline \multirow{2}{*}{$\begin{array}{l}\text { Sites } \\
\text { Species }\end{array}$} & \multirow[t]{2}{*}{ Statistics } & \multicolumn{5}{|l|}{ LDS } & \multicolumn{5}{|l|}{ SDS } \\
\hline & & LF-P & LFl-S & LFL-P & Flw-S & Flw-P & LF-P & LFl-S & LFL-P & Flw-S & Flw-P \\
\hline \multirow[t]{4}{*}{ B. crassifolia } & Mean date & Oct $\left(295.8^{\circ}\right)$ & Oct $\left(270.1^{\circ}\right)$ & $\operatorname{Dec}\left(330.2^{\circ}\right)$ & Oct $\left(284^{\circ}\right)$ & $\operatorname{Nov}\left(308.7^{\circ}\right)$ & Aug $\left(233.6^{\circ}\right)$ & Sep $\left(263.9^{\circ}\right)$ & Oct $\left(279.5^{\circ}\right)$ & Oct $\left(269.9^{\circ}\right)$ & Oct $\left(282.8^{\circ}\right)$ \\
\hline & LMV (r) & 0.92 & 0.72 & 0.84 & 0.89 & 0.89 & 0.82 & 0.83 & 0.82 & 0.9 & 0.93 \\
\hline & Rayleigh & $17.74^{*}$ & $11.37^{*}$ & $15.54^{*}$ & $16.81^{*}$ & $16.62^{*}$ & $72.04^{*}$ & $91.13^{*}$ & $87.68^{*}$ & $66.78^{*}$ & $71.85^{*}$ \\
\hline & Test (Z) & & & & & & & & & & \\
\hline \multirow[t]{4}{*}{ C. coriaceum } & Mean date & Sep $\left(268.5^{\circ}\right)$ & $\operatorname{Sep}\left(263.6^{\circ}\right)$ & $\operatorname{Nov}\left(304.1^{\circ}\right)$ & Oct $\left(279^{\circ}\right)$ & Oct $\left(287.5^{\circ}\right)$ & Aug $\left(210.9^{\circ}\right)$ & Aug $\left(220.4^{\circ}\right)$ & Sep $\left(244.5^{\circ}\right)$ & Aug $\left(225.2^{\circ}\right)$ & Aug $\left(220.8^{\circ}\right)$ \\
\hline & LMV (r) & 0.86 & 0.75 & 0.65 & 0.87 & 0.92 & 0.85 & 0.71 & 0.75 & 0.96 & 0.99 \\
\hline & Rayleigh & $17.86^{*}$ & $14.74^{*}$ & $9.59^{*}$ & $8.89^{*}$ & $10.07^{*}$ & $31.6^{*}$ & $24.08^{*}$ & $26.8^{*}$ & $6.49^{*}$ & $6.92^{*}$ \\
\hline & Test (Z) & & & & & & & & & & \\
\hline \multirow[t]{4}{*}{ H. ciliata } & Mean date & Jul (199.6º & Jul (197.6º & Sep $\left(252.6^{\circ}\right)$ & $\operatorname{Sep}\left(249.7^{\circ}\right)$ & Out $\left(274.7^{\circ}\right)$ & Jun $\left(176.6^{\circ}\right)$ & Aug $\left(212.4^{\circ}\right)$ & Aug $\left(222.4^{\circ}\right)$ & $\operatorname{Aug}\left(223.3^{\circ}\right)$ & Aug $\left(236.9^{\circ}\right)$ \\
\hline & LMV (r) & 0.45 & 0.67 & 0.8 & 0.96 & 0.91 & 0.94 & 0.87 & 0.92 & 0.94 & 0.96 \\
\hline & Rayleigh & $6.02^{*}$ & $17.86^{*}$ & $23.02^{*}$ & $29.51^{*}$ & $25.77^{*}$ & $7.95^{*}$ & $32.72^{*}$ & $35.66^{*}$ & $30^{*}$ & $32.36^{*}$ \\
\hline & Test (Z) & & & & & & & & & & \\
\hline \multirow[t]{4}{*}{ Q. grandiflora } & Mean date & $\operatorname{Nov}\left(317.9^{\circ}\right)$ & $\operatorname{Dec}\left(348.9^{\circ}\right)$ & $\operatorname{Jan}\left(8.1^{\circ}\right)$ & Feb $\left(53.7^{\circ}\right)$ & Feb $\left(55.12^{\circ}\right)$ & Sep $\left(261.5^{\circ}\right)$ & Oct $\left(269.9^{\circ}\right)$ & $\operatorname{Nov}\left(312.3^{\circ}\right)$ & $\operatorname{Dec}\left(345.8^{\circ}\right)$ & $\operatorname{Dec}\left(339.7^{\circ}\right)$ \\
\hline & LMV (r) & 0.89 & 0.81 & 0.86 & 0.91 & 0.9 & 0.88 & 0.72 & 0.79 & 0.93 & 0.52 \\
\hline & Rayleigh & $34.6^{*}$ & $37.01^{*}$ & $38.93^{*}$ & $19.03^{*}$ & $18.86^{*}$ & $72.8^{*}$ & $50.26^{*}$ & $54.83^{*}$ & $12.05^{*}$ & $3.84^{*}$ \\
\hline & Test (Z) & & & & & & & & & & \\
\hline \multirow[t]{4}{*}{ P. reticulata } & Mean date & $\operatorname{Nov}\left(304.8^{\circ}\right)$ & $\operatorname{Dec}\left(350.6^{\circ}\right)$ & $\operatorname{Jan}\left(0.9^{\circ}\right)$ & $\operatorname{Dec}\left(356.9^{\circ}\right)$ & $\operatorname{Dec}\left(358.2^{\circ}\right)$ & Ago $\left(26.9^{\circ}\right)$ & Set $\left(257.4^{\circ}\right)$ & Oct $\left(276.7^{\circ}\right)$ & na & na \\
\hline & LMV (r) & 0.95 & 0.86 & 0.85 & 0.93 & 0.98 & 0.94 & 0.84 & 0.91 & & \\
\hline & Rayleigh & $64.09^{*}$ & $52.98^{*}$ & $51.35^{*}$ & $62.51^{*}$ & $69.50^{*}$ & $23.43^{*}$ & $17.87^{*}$ & $21.72^{*}$ & & \\
\hline & Test (Z) & & & & & & & & & & \\
\hline
\end{tabular}

Table 2

Watson Williams test results for comparisons among the mean start and peak dates for leaf fall, leaf flushing and flowering in savanna species subjected to longer (LDS) and shorter dry season (SDS), Maranhão State, Brazil. LF = leaf fall; LFl = leaf flushing; $\mathrm{Flw}=$ flowering; $\mathrm{S}=$ start; $\mathrm{P}=$ peak; na = not available. $\mathrm{F}=$ circular statistical value; $p=$ probability value.

\begin{tabular}{lllllll}
\hline Species & Statistics & LF-P & LFl-S & LFl-P & Flw-S & Flw-P \\
\hline B. crassifolia & $\mathrm{F}$ & 61.219 & 0.45 & 36.856 & 3.528 & 20.243 \\
& $\mathrm{p}$ & $<0.001$ & 0.503 & $<0.001$ & 0.063 & $<0.001$ \\
C. coriaceum & $\mathrm{F}$ & 47.601 & 14.405 & 22.015 & 16.67 & 16.096 \\
& $\mathrm{p}$ & $<0.001$ & $<0.001$ & $<0.001$ & $<0.001$ & $<0.001$ \\
H. ciliata & $\mathrm{F}$ & 1.155 & 2.584 & 18.046 & 33.029 & 54.258 \\
& $\mathrm{p}$ & 0.289 & 0.112 & $<0.001$ & $<0.001$ & $<0.001$ \\
Q. grandiflora & $\mathrm{F}$ & 115.156 & 116.974 & 78.434 & 65.327 & 20.071 \\
& $\mathrm{p}$ & $<0.001$ & $<0.001$ & $<0.001$ & $<0.001$ & $<0.001$ \\
P. reticulata & $\mathrm{F}$ & 76.517 & 63.753 & 67.109 & $\mathrm{na}$ & na \\
& $\mathrm{p}$ & $<0.001$ & $<0.001$ & $<0.001$ & & \\
\hline
\end{tabular}

were concentrated between November and February in LDS, and between September and December in SDS. The delay for this species was about two to almost three months (Table 1), with different mean start and peak dates (Table 2). The highest proportions of all SDS phenophases preceded those of LDS (Fig. 3). The leaf flushing and flowering pattern in LDS, referring to the phenophases duration, was not verified for this species (Fig. 3).

Phenological events in $P$. reticulata differed between sites (Table 2), with start and peak dates distributed from November to January in LDS and from August to October in SDS, with a delay of three months for all phenophases in LDS (except to Flow-S and Flow-P) (Table 1). Considering the intensity of events, we observed the same pattern of earlier occurrence in SDS and a longer leaf flushing duration in LDS (Fig. 3).

We found that maximum (positive trend) or minimum air temperatures (mostly negative trend) and day length were significantly associated with the intensity of the phenophases (Table 3). For most species, leaf fall, increased as maximum temperature increase at both sites, but it was also associated with a decrease of minimum temperatures in SDS. Day length also had a negative association with leaf fall in C. coriaceum and $H$. ciliata, for both sites (Table 3 ). For all species in SDS, except to $H$. ciliata, leaf flushing was related to the temperature (positive trend). In LDS, B. crassifolia, Q. grandiflora and P. reticulata showed association between leaf flushing and day length (positive trend), while for $C$. coriaceum and $H$. ciliata, maximum temperature (positive trend) and precipitation (negative trend) were, respectively, more associated with leaf flushing (Table 3). Flowering was not associated with climatic variables in $C$. coriaceum and $P$. reticulata (Table 3). For $B$. crassifolia, flowering was related to increases in maximum temperature at both sites. For $H$. ciliata, this event was associated with the decrease of the minimum temperature in SDS and an increase of the maximum temperature in LDS. Q. grandiflora exhibited significant relationship between flowering and day length in SDS (Table 3).

\section{Discussion}

Our results support the hypothesis that phenological phenomena are intrinsically linked to climatic variables, especially temperature and day length, independent of the site. We also confirm that a shorter dry season, in comparison to a longer dry season, promotes earlier occurrence of phenological patterns, because temperature and day length reaches a greater variation earlier at SDS site than at the LDS. The conspecific populations of the five evaluated species showed distinct behavior for all phenological events between the two sites, with differences in the start and peak dates. Peak dates generally occurred about one to three months later in LDS. This difference may represent levels of local adaptation and a high degree of phenotypic plasticity related to adjustments for the selective abiotic pressures driving leaf and flower production (Pellissier et al., 2014; Panchen and Gorelick, 2016; Silva Moraes et al., 2017).

The start and peak dates and the highest proportions of leaf fall intensity for the conspecific populations occurred at different times during drought in each area, accompanying the variations in temperature and/or decrease in day length at both sites. The association between temperature and leaf fall is presumably related to the increase in evaporative demand and water stress, with consequent loss of leaves, which was already reported for some savanna areas in Brazil (Bulhão and Figueiredo, 2002; Silvério and Lenza, 2010). As for the relationship with day length, this variable decreases during the early dry period, and may also function as a factor associated with leaf fall (Garcia et al., 2017), signaling climatic changes. Day lengh is the only variable correlated with leaf fall in $H$. ciliata at both sites, and was included among the variables related to leaf fall in C.coriaceum. The species B. crassifolia 
Table 3

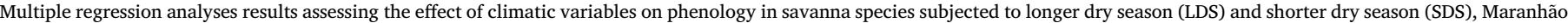

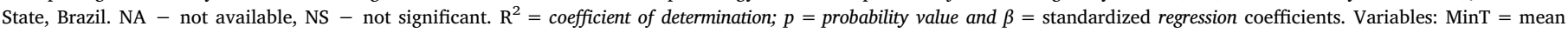
minimum air temperature; MaxT = mean maximum air temperature; DL = day length; Ppt = precipitation.

\begin{tabular}{|c|c|c|c|c|c|c|}
\hline \multirow[t]{2}{*}{ Species } & \multicolumn{3}{|l|}{ LDS } & \multicolumn{3}{|l|}{ SDS } \\
\hline & Leaf fall & Leaf flushing & Flowering & Leaf fall & Leaf flushing & Flowering \\
\hline B. crassifolia & $\begin{array}{l}\mathrm{R}^{2}=0.70 \mathrm{p} \leq 0.01 \\
\text { MaxT } \beta=4.3 \\
\text { MinT } \beta=7.3\end{array}$ & $\begin{array}{l}\mathrm{R}^{2}=0.71 \mathrm{p} \leq 0.01 \\
\mathrm{DL} \beta=97.27\end{array}$ & $\begin{array}{l}\mathrm{R}^{2}=0.74 \mathrm{p} \leq 0.01 \\
\operatorname{MaxT} \beta=7.3\end{array}$ & $\begin{array}{l}\mathrm{R}^{2}=0.77 \mathrm{p} \leq 0.01 \\
\text { MaxT } \beta=2.82 \\
\text { MinT } \beta=-4.35\end{array}$ & $\begin{array}{l}\mathrm{R}^{2}=0.63 \mathrm{p} \leq 0.01 \\
\operatorname{MaxT} \beta=2.65\end{array}$ & $\begin{array}{l}\mathrm{R}^{2}=0.62 \mathrm{p} \leq 0.01 \\
\operatorname{MaxT} \beta=2.69\end{array}$ \\
\hline C. coriaceum & $\begin{array}{l}\mathrm{R}^{2}=0.57 \mathrm{p} \leq 0.01 \\
\text { MaxT } \beta=6.0 \\
\text { DL } \beta=-13.2\end{array}$ & $\begin{array}{l}\mathrm{R}^{2}=0.75 \mathrm{p} \leq 0.01 \\
\operatorname{MaxT} \beta=4.4\end{array}$ & NS & $\begin{array}{l}\mathrm{R}^{2}=0.77 \mathrm{p} \leq 0.01 \\
\text { MinT } \beta=-3.23 \\
\mathrm{DL} \beta=-26.61\end{array}$ & $\begin{array}{l}\mathrm{R}^{2}=0.72 \mathrm{p} \leq 0.01 \\
\text { MaxT } \beta=4.7 \\
\text { MinT } \beta=-4.6\end{array}$ & NS \\
\hline H. ciliata & $\begin{array}{l}\mathrm{R}^{2}=0.44 \mathrm{p} \leq 0.05 \\
\mathrm{DL} \beta=-81.56\end{array}$ & $\begin{array}{l}\mathrm{R}^{2}=0.55 \mathrm{p} \leq 0.01 \\
\text { Ppt } \beta=-0.01\end{array}$ & $\begin{array}{l}\mathrm{R}^{2}=0.61 \mathrm{p} \leq 0.01 \\
\operatorname{MaxT} \beta=4.12\end{array}$ & $\begin{array}{l}\mathrm{R}^{2}=0.62 \mathrm{p} \leq 0.01 \\
\mathrm{DL} \beta=-31.64\end{array}$ & NS & $\begin{array}{l}\mathrm{R}^{2}=0.47 \mathrm{p} \leq 0.05 \\
\text { MinT } \beta=-5.02\end{array}$ \\
\hline Q. grandiflora & $\begin{array}{l}\mathrm{R}^{2}=0.67 \mathrm{p} \leq 0.01 \\
\operatorname{MaxT} \beta=5.57\end{array}$ & $\begin{array}{l}\mathrm{R}^{2}=0.71 \mathrm{p} \leq 0.01 \\
\mathrm{DL} \beta=178.3\end{array}$ & $\begin{array}{l}\text { NS } \\
-\end{array}$ & $\begin{array}{l}\mathrm{R}^{2}=0.67 \mathrm{p} \leq 0.01 \\
\operatorname{MaxT} \beta=11.52\end{array}$ & $\begin{array}{l}\mathrm{R}^{2}=0.73 \mathrm{p} \leq 0.01 \\
\operatorname{MaxT} \beta=4.44\end{array}$ & $\begin{array}{l}\mathrm{R}^{2}=0.65 \mathrm{p} \leq 0.01 \\
\mathrm{DL} \beta=0.45\end{array}$ \\
\hline P. reticulata & $\begin{array}{l}\mathrm{R}^{2}=0.92 \mathrm{p} \leq 0.01 \\
\operatorname{MaxT} \beta=11.32\end{array}$ & $\begin{array}{l}\mathrm{R}^{2}=0.91 \mathrm{p} \leq 0.01 \\
\mathrm{DL} \beta=0.55\end{array}$ & NS & $\begin{array}{l}\mathrm{R}^{2}=0.92 \mathrm{p} \leq 0.01 \\
\operatorname{MaxT} \beta=7.66 \\
\operatorname{MinT} \beta=-10.9\end{array}$ & $\begin{array}{l}\mathrm{R}^{2}=0.59 \mathrm{p} \leq 0.01 \\
\operatorname{MaxT} \beta=4.64\end{array}$ & NA \\
\hline
\end{tabular}

NS $=$ not significant.

shows different degrees of leaf deciduousness, with greater crown cover and smaller variations in the proportions of leaf fall in LDS. The $H$. ciliata species also showed lower seasonality for this event (shorter length of vector $r$ ) in this area. We can postulate that these differences in the degree of intraspecific deciduousness among Cerrado species are indicative of high levels of plasticity against climatic aspects (Kuster et al., 2017), which allows them to cope with very distinct climatic regions of the Brazilian territory.

Leaf flushing showed generally consistent differences in the start and peak dates with distinct distribution of the intensity percentage throughout the year for both sites. This confirms the occurrence of the pre-rain green-up phenomenon reported for some savanna species in Central Brazil (Rivera et al., 2002; Franco et al., 2005; Silvério and Lenza, 2010; Dalmolin et al., 2015). This phenomenon is characterized by the appearance of new leaves before the rainy season. This strategy is reported to avoid plant nutrient losses due to herbivory or leaching (Van Schaik et al., 1993); to maximize carbon gain by increasing $\mathrm{CO}_{2}$ assimilation (Rossatto et al, 2009; Dalmolin et al., 2015) and to make the best use of available nutrients in the soil as rainfall increases (Scholes and Walker, 2004; Nord and Lynch, 2009). During the pre-rain green-up, plants take advantage of the higher temperatures to quickly produce and expand their leaves. The influence of temperature on leaf flushing has been reported in tropical seasonally dry regions, such as savannas in Brazil (Pirani et al., 2009; Silvério and Lenza, 2010) and Africa (Seghieri et al., 2012) and may be a key variable for this process (Chambers et al., 2013). The delayed leaf production at LDS site (compared to plants in SDS) may be an adjustment to avoid overexposure of leaves produced during the dry season, which can decrease productivity in savanna plants.

The influence of day length has been reported as a trigger factor for leaf flush and flowering events in tropical regions, including savanna areas (Rivera et al., 2002; Yeang, 2007; Renner, 2007; Zimmerman et al., 2007; Pau et al., 2013; Borchert et al., 2015; Ryan et al., 2017). Although the results of the multiple regression did not show a clear relationship between the phenophases and day length, the leaf flush for all the species in LDS, except $H$. ciliata, increased considerably during the end of the dry period, when day length increases. In SDS, the increase in leaf flushing during the middle and end of the dry period occurs when there is a decrease in clouds and a higher incidence of solar radiation. Thus, as photosynthetic rates are higher in young leaves, the production of new leaves during the period of greater day length and/or irradiance favors photosynthesis and carbon gain (Wright and Van Schaik, 1994), since savanna plants has specific mechanisms to use and store water during the dry season (Goldstein et al., 2008). Therefore, the occurrence of production and growth phenophases during the period of low or no precipitation, indicates the existence of mechanisms that allow plants to rehydrate or maintain internal water levels (Worbes et al., 2013) and are favored by the transfer of assimilated products, which link directly to the growth organs and promote the production of leaves (Ryan et al., 2017) flowers and fruits (Pau et al., 2013; Zimmerman et al., 2007; Camargo et al., 2011; Borchert et al., 2015).

Flowering, which followed the trend of earlier occurrence in SDS, was less related to the climatic variables of each site. However, in $B$. crassifolia and $H$. ciliata, flowering was associated with variations in temperature during the dry period, and in Q. grandiflora, it was associated with the increased day length in SDS during the early rainy season. Although the populations of other species did not show significant results in relation to climatic variables, they showed a degree of seasonality compatible with different flowering strategies. Flowering occurred in $C$. coriaceum at both sites during the dry period, under higher irradiance and temperatures, and in Q. grandiflora in LDS, during early rainy season, with increased day length. $P$. reticulata in LDS had its flowering peak in the final days of the dry period. Thus, for both the evergreen species and the deciduous species, the water restriction in the environment does not limit flowering in general (Lenza and Klink, 2006; Tannus et al., 2006; Figueiredo, 2008; Pirani et al., 2009; Camargo et al., 2011; Silva et al., 2011; Barbosa et al., 2012). Regarding temperature, it is widely recognized as a variable that affects plant distribution and metabolism, and is an important requirement for flowering (Grace, 1987). Its influence on leaf production and flowering in savannas appears to be more important than the influence of water availability in dry and wet season (Seghieri et al., 2012).

In summary, we characterized the phenological responses in conspecific populations under distinct climates, showing that temperature and day length are the major drivers for phenological events, independent of the site. The duration of the dry season does not limit growth phenomena, but shorter dry seasons allows plants to produce leaves and flowers earlier than under longer dry seasons, because temperature and day length start to increase earlier in SDS site. This strategy indicates higher phenotypic plasticity in savanna woody plants, aligned with adjustments to maximize carbon gain and reproductive success.

\section{Acknowledgments}

We thank Prof. Patricia Maia Albuquerque, Maria Antonia de Melo and Éville Ribeiro for support in the execution of the project; Zoe Panchen for initial reading and suggestions; Davi B. Muniz for the map illustration; and the members of the Laboratorio de Estudos Botânicos, 
especially Ariade Nazareth da Silva, Bruna Correia, and Gustavo Lima for their participation in the collection and identification of species. This work was supported by Fundação de Amparo à Pesquisa e ao Desenvolvimento Científico e Tecnológico do Maranhão - FAPEMA (Projeto APP-UNIVERSAL - 00744/13).

\section{Appendix A. Supplementary data}

Supplementary data associated with this article can be found, in the online version, at http://dx.doi.org/10.1016/j.flora.2017.10.001.

\section{References}

Alvares, C.A., Stape, J.L., Sentelhas, P.C., de Moraes, G., Leonardo, J., Sparovek, G., 2013. Köppen's climate classification map for Brazil. Meteorol. Zeitschrift 22, 711-728.

Barbosa, R.I., Mourão Jr., M., Casadio, G.M.L., da Silva, S.J.R., 2012. Reproductive phenology of the main tree species in the Roraima savanna, Brazilian Amazon. Ecotropica 18, 81-91.

Batalha, M.A., Martins, F.R., 2004. Reproductive phenology of the cerrado plant community in Emas National Park (central Brazil). Aust. J. Bot. 52, 149-161.

Borchert, R., Calle, Z., Strahler, A.H., Baertschi, A., Magill, R.E., Broadhead, J.S., Kamau, J., Njoroge, J., Muthuri, C., 2015. Insolation and photoperiodic control of tree development near the equator. New Phytol. 205, 7-13.

Borges, M.P., Prado, C.H.B., 2014. Relationships between leaf deciduousness and flowering traits of woody species in the Brazilian neotropical savanna. Flora 209, 73-80.

Bridgewater, S., Ratter, J.A., Ribeiro, J.F., 2004. Biogeographic patterns, $\beta$-diversity and dominance in the cerrado biome of Brazil. Biodivers. Conserv. 13, 2295-2317.

Bulhão, C.F., Figueiredo, P.S., 2002. Phenology of leguminous trees in an area of cerrado in the northeast of Maranhão. Braz. J. Bot. 25, 361-369.

Camargo, M.G.G., Souza, R.M., Reys, P., Morellato, L.P., 2011. Effects of environmental conditions associated to the cardinal orientation on the reproductive phenology of the cerrado savanna tree Xylopia aromatica (Annonaceae). An. Acad. Bras. Cienc. 83, 1007-1020.

Chambers, L.E., Altwegg, R., Barbraud, C., Barnard, P., Beaumont, L.J., Crawford, R.J., Durant, J.M., Hughes, L., Keatley, M.R., Low, M., Morellato, P.C., Poloczanska, E.S., Ruoppolo, V., Vanstreels, R.E.T., Woehler, E.J., Wolfaardf, A.C., 2013. Phenological changes in the southern hemisphere. PLoS One 8.

Dalmolin, Â.C., de Almeida Lobo, F., Vourlitis, G., Silva, P.R., Dalmagro, H.J., Antunes, M.Z., Ortíz, C.E.R., 2015. Is the dry season an important driver of phenology and growth for two Brazilian savanna tree species with contrasting leaf habits? Plant Ecol. 216, 407-417.

Diez, J.M., Ibánzes, I., Miller-Rushing, A.J., Mazer, S.J., Crimmins, T.M., Crimmins, M.A., Bertelsen, C.D., Inouye, D.W., 2012. Forecasting phenology: from species variability to community patterns. Ecol. Lett. 15, 545-553.

Figueiredo, P.S., 2008. Fenologia e estratégias reprodutivas das espécies arbóreas em uma área marginal de cerrado, na transição para o semi-árido no nordeste do Maranhão, Brasil. Rev. Trop. Cienc. Agrar. Biol. 2, 8-21.

Forrest, J., Miller-Rushing, A.J., 2010. Toward a synthetic understanding of the role of phenology in ecology and evolution. Philos. Trans. R. Soc. Lond. B. Biol. Sci. 365, 3101-3112.

Forrest, J., Inouye, D.W., Thomson, J.D., 2010. Flowering phenology in subalpine meadows: does climate variation influence community co-flowering patterns? Ecology 91, 431-440.

Fournier, L.A., 1974. A quantitative method for the measurement of phenological characteristics in trees. Turrialba 24, 422-423.

Franco, A.C., Bustamante, M.M.C., Caldas, L.S., Goldstein, G., Meinzer, F.C., Kozovits, A.R., Rundel, P., Coradin, V.T.R., 2005. Leaf functional traits of Neotropical savanna trees in relation to seasonal water deficit. Trees 19, 326-335.

Franco, A.C., Rossatto, D.R., Silva, L.D.C.R., da Silva Ferreira, C., 2014. Cerrado vegetation and global change: the role of functional types: resource availability and disturbance in regulating plant community responses to rising $\mathrm{CO}^{2}$ levels and climate warming. Theor. Exp. Plant Physiol. 261, 19-38.

Garcia, L.C., Barros, F.V., Lemos-Filho, J.P., 2017. Environmental drivers on leaf phenology of ironstone outcrops species under seasonal climate. An. Acad. Bras. Cienc. 89, 131-143.

Goldstein, G., Meinzer, F.C., Bucci, S.J., Scholz, F.G., Franco, A.C., Hoffmann, W.A., 2008. Water economy of Neotropical savanna trees: six paradigms revisited. Tree Physiol. 28, 395-404.

Goulart, M.F., Lemos Filho, J.P., Lovato, M.B., 2005. Phenological variation within and among populations of Plathymenia reticulata in Brazilian Cerrado, the Atlantic Forest and transitional sites. Ann. Bot. 96, 445-455.

Grace, J., 1987. Climatic tolerance and the distribution of plants. New Phytol. 106, $113-130$.

Grogan, J., Schulze, M., 2012. The impact of annual and seasonal rainfall patterns on growth and phenology of emergent tree species in southeastern Amazonia, Brazil. Biotropica 44, 331-340.

Guan, K., Wood, E.F., Medvigy, D., Kimball, J., Pan, M., Caylor, K.K., Shefield, J., Xu, X., Jones, M.O., 2014. Terrestrial hydrological controls on land surface phenology of African savannas and woodlands. J. Geophys. Res. Biogeosci. 119, 1652-1669.

Hawes, J.E., Peres, C.A., 2016. Patterns of plant phenology in Amazonian seasonally flooded and unflooded forests. Biotropica 48, 465-475.
Kovach, W.L., 2011. Oriana-circular Statistics for Windows, Ver. 4. Kovach Computing Services, Pentraeth.

Kushwaha, C.P., Tripathi, S.K., Tripathi, B.D., Singh, K.P., 2011. Patterns of tree phenological diversity in dry tropics. Acta Ecol. Sinica 31, 179-185.

Kuster, V.C., de Castro, S.A.B., Vale, F.H.A., 2017. Environmental conditions modulate plasticity in the physiological responses of three plant species of the Neotropical savannah. Acta Physiol. Plant 39, 103.

Lenza, E., Klink, C.A., 2006. Comportamento fenológico de espécies lenhosas em um cerrado sentido restrito de Brasília, DF. Rev. Bras. Bot. 29, 627-638.

Nord, E.A., Lynch, J.P., 2009. Plant phenology: a critical controller of soil resource acquisition. J. Exp. Bot. 60, 1927-1937.

Nord, E.A., Shea, K., Lynch, J.P., 2011. Optimizing reproductive phenology in a tworesource world: a dynamic allocation model of plant growth predicts later reproduction in phosphorus-limited plants. Ann. Bot. 108, 391-404.

Panchen, Z.A., Gorelick, R., 2016. Canadian arctic archipelago conspecifics flower earlier in the high arctic than the mid-Arctic. Int. J. Plant Sci. 177, 661-670.

Pau, S., Wolkovich, E.M., Cook, B.I., Davies, T.J., Kraft, N.J., Bolmgren, K., Betancourt, J.L., Cleland, E.E., 2011. Predicting phenology by integrating ecology, evolution and climate science. Global Chang. Biol. 17, 3633-3643.

Pau, S., Wolkovich, E.M., Cook, B.I., Nytch, C.J., Regetz, J., Zimmerman, J.K., Wright, S.J., 2013. Clouds and temperature drive dynamic changes in tropical flower production. Nat. Clim. Chang. 3, 838-842.

Pellissier, L., Roger, A., Bilat, J., Rasmann, S., 2014. High elevation Plantago lanceolata plants are less resistant to herbivory than their low elevation conspecifics: is it just temperature? Ecography 37, 950-959.

Pirani, F.R., Sanchez, M., Pedroni, F., 2009. Fenologia de uma comunidade arbórea em cerrado sentido restrito, Barra do Garças, MT, Brasil. Acta Bot. Bras. 23, 1096-1109.

Renner, S.S., 2007. Synchronous flowering linked to changes in solar radiation intensity. New Phytol. 175, 195-197.

Rivera, G., Elliott, S., Caldas, L.S., Nicolossi, G., Coradin, V.T., Borchert, R., 2002. Increasing day-length induces spring flushing of tropical dry forest trees in the absence of rain. Trees Struct. Funct. 16, 445-456.

Rossatto, D.R., Hoffmann, W.A., Franco, A.C., 2009. Differences in growth Patterns between co-occuring forest and savanna tress affect the forest-savanna boundary. Funct. Ecol. 23, 689-698.

Rossatto, D.R., 2013. Seasonal patterns of leaf production in co-occuring trees with contrasting leaf phenology: time and quantitative divergences. Plant Species Biol. 28, 138-145.

Ryan, C.M., Williams, M., Frace, J., Woollen, W., Lehmann, C.E., 2017. Pre-rain green up is ubiquitos acrros tropical Africa: implications for temporal niche separation and model representation. New Phytol. 213, 625-633.

Scholes, R.J., Walker, B.H., 2004. An African Savanna: Synthesis of the Nylsvley Study. Cambridge University Press, Cambridge, UK.

Seghieri, J., Carreau, J., Boulain, N., de Rosnay, P., Arjounin, M., Timouk, F., 2012. Is water availability really the main environmental factor controlling the phenology of woody vegetation in the central Sahel? Plant Ecol. 213, 861-870.

Silvério, D.V., Lenza, E., 2010. Phenology of woody species in a typical cerrado in the Bacaba Municipal Park, Nova Xavantina, Mato Grosso, Brazil. Biota Neotropica 10, 205-216.

Silva Moraes, A.C., da Vitória, A.P., Rossatto, D.R., de Miranda, L.D.A.P., Funch, L.S., 2017. Leaf phenology and morphofunctional variation in Myrcia amazonica DC. (Myrtaceae) in gallery forest and campo rupestre vegetation in the Chapada Diamantina, Brazil. Braz. J. Bot. 1-12.

Silva, F.A.M., Assad, E.D., Evangelista, B.A., 2008. Caracterização Climática do Bioma Cerrado. In: Sano, S.M., Almeida, S.P., Oliveira, P.E. (Eds.), Cerrado: ecologia e flora EMBRAPA-CPAC, Planaltina, Brasil, pp. 71-88.

Silva, I.A., da Silva, D.M., de Carvalho, G.H., Batalha, M.A., 2011. Reproductive phenology of Brazilian savannas and riparian forests: environmental and phylogenetic issues. Ann. For. Sci. 68, 1207-1215.

Stevenson, P.R., Castellanos, M.C., Cortés, A.I., Link, A., 2008. Flowering patterns in a seasonal tropical lowland forest in western Amazonia. Biotropica 40, 559-567.

Tang, J., Körner, C., Muraoka, H., Piao, S., Shen, M., Thackeray, S.J., Yang, X., 2016. Emerging opportunities and challenges in phenology: a review. Ecosphere 7, 1-17.

Tannus, J.L.S., Assis, M.A., Morellato, P.C., 2006. Reproductive Phenology in Dry and Wet Grassland in an Area of Cerrado at Southeastern Brazil, Itirapina. -SP. Biota Neotropica. http://www.scielo.br/scielo.php?script=sci_arttext\&pid = S1676 06032006000300008.

Van Schaik, C.P., Terborgh, J.W., Wright, S.J., 1993. The phenology of tropical forests: adaptive significance and consequences for primary consumers. Annu. Rev. Ecol. Syst. 24, 353-377.

Worbes, M., Blanchart, S., Fichtler, E., 2013. Relations between water balance, wood traits and phenological behavior of tree species from a tropical dry forest in Costa Rica-a multifactorial study. Tree Physiol. 33, 527-536.

Wright, S.J., Van Schaik, C.P., 1994. Light and the phenology of tropical trees. Am. Nat. 143, 192-199.

Yeang, H.Y., 2007. Synchronous flowering of the rubber tree (Hevea brasiliensis) induced by high solar radiation intensity. New Phytol. 175, 283-289.

Zalamea, P.C., Munoz, F., Stevenson, P.R., Paine, C.T., Sarmiento, C., Sabatier, D., Heuret, P., 2011. Continental-scale patterns of Cecropia reproductive phenology: evidence from herbarium specimens. Proc. R. Soc. Lond. B. Biol. Sci. 278, 2437-2445.

Zar, J.H., 2010. Biostatistical Analysis. Prentice-Hall, New Jersey.

Zimmerman, J.K., Wright, S.J., Calderón, O., Pagan, M.A., Paton, S., 2007. Flowering and fruiting phenologies of seasonal and aseasonal neotropical forests: the role of annual changes in irradiance. J. Trop. Ecol. 23, 231-251. 